Article

\title{
Teachers' Perceptions of the Use of ICTs in the Educational Response to Students with Disabilities
}

\author{
Luis Ortiz-Jiménez *®) Victoria Figueredo-Canosa $₫$, Macarena Castellary López and \\ María Carmen López Berlanga $₫$ \\ Department of Education, Faculty of Education Sciences, University of Almeria, 04120 Almería, Spain; \\ vfc310@ual.es (V.F.-C.); mcl142@ual.es (M.C.L.); berlanga@ual.es (M.C.L.B.) \\ * Correspondence: lortizj@ual.es
}

Received: 20 October 2020; Accepted: 11 November 2020; Published: 13 November 2020

\begin{abstract}
The educational response to students with specific needs for educational support associated with disability could not be understood within the current educational landscape without addressing how Information and Communication Technology (ICT) is used within those responses. ICT support is not a matter of fashion or one-off use due to the current circumstances brought about by the effects of the COVID-19 pandemic. Programmes and materials are already being developed to enable such application. Even from the Universal Learning Design approaches, it is precisely the use of technologies in learning processes, with special emphasis on educational inclusion processes, which are a key focus. This study deals with the perception that teachers have of this use of ICT with students with disabilities: How are the resources available to them and how good is their training in this respect? To do this, a section of a questionnaire was used, which forms part of the R + D + I project awarded under a national call in Spain, and which in one of its categories precisely focuses attention on this use of ICT. In turn, this category, according to the confirmatory factor analysis carried out, is subdivided into three subcategories: didactic use, spaces and resources, and finally teacher training. We are also interested in knowing if there are differences of opinion between population groups grouped according to sex, ownership of the education centre and location of the centre (urban, or rural). The results indicate that although there is good use and good preparation of teachers, the level of resources is low and teacher training needs to be reinforced.
\end{abstract}

Keywords: disability; information and communication technologies; universal learning design; teacher training

\section{Introduction}

Information and Communication Technologies (ICTs) have made a decisive breakthrough in the social world, modifying cultural references in different areas of daily life [1]. In the field of education, ICTs have become an effective tool for mediating and promoting learning [2]. The correct use facilitates active, versatile, flexible and adaptable learning [3]; favouring participation, communication and the carrying out of tasks adjusted to people's possibilities and interests $[4,5]$. However, apart from its potential as a learning mediation tool, ICT opens up a wide range of educational opportunities for students with special educational needs, favouring the overcoming of limitations derived from disabilities: autonomy, communication, participation, motivation, personalised teaching, the flexibility of learning rhythms and times, the reduction in the sense of academic and personal failure, etc. [6-12]. ICT has the potential to improve the quality of life of people with disabilities, reduce their social exclusion and increase their participation [13]. Taking this premise into account, the Action Plan of the Spanish Disability Strategy 2014-2020 [14] includes two outstanding actions referred to in Operational Objective 1 (Supporting educational centres in 
the process towards inclusion): (a) ensuring that students with disabilities have the human and technological resources available, and access to information and communication, mobility or any other kind of resources at all educational stages; and (b) favouring technological projects aimed at improving accessibility in the educational system. These guidelines reveal the importance given at national level to ICTs in the process of inclusion of people with disabilities.

In the development of Universal Learning Design, special importance is given to the incorporation of ICT for an adequate application of its principles [15-17].

However, as pointed out in different studies, sometimes ICTs, depending on their design and implementation, can also enhance access difficulties by becoming exclusionary tools [18-24]. In this sense, it is important to bear in mind that ICTs must comply with usability and accessibility standards in order to avoid the digital disability divide [25].

Within the Spanish educational framework, the State Observatory on Disability [26] has published a report which sets out various challenges for progress towards inclusive education, including: eradicating the traditional model of teaching which predominates, alleviating the shortage of resources and strengthening teacher training. In response to these challenges, this study distinguishes three categories of analysis:

Didactic Aspects (DIDTIC) covers the incorporation of ICT in the didactic programmes, as well as its implementation to adapt the learning processes to the students with disabilities, to carry out the evaluation of their learning and to favour the collaboration between the students. The study by Arnaiz, De Haro and Maldonado [27], carried out by means of a questionnaire to 86 participants, points out that there are certain aspects related to teaching methodology that represent barriers to progressing towards inclusion, such as: the lack of methodological diversity and teaching strategies in teaching practices; the absence of necessary adaptations and multi-level teaching; non-individualised response, etc. Faced with these barriers, the ULD approach (Universal Learning Design) takes on special relevance, taking into account that it allows the potential of technological resources to be used to favour diversity of access, content and communication $[3,28]$. On the other hand, the study by Estes, Beverly and Castillo [29], carried out by means of a bibliographic review, points out the importance of promoting collaborative approaches when designing learning experiences for students with and without disabilities.

Spaces and Resources (ESPTIC) focuses on the organisation and availability of technological resources to attend to students with disabilities. In the study carried out by González-Gil et al. [30], conducted through ten focus groups with 80 teachers, it was shown that the scarcity of resources, of different types, makes it impossible implement the correct practices to achieve inclusion. The study by Arnaiz, De Haro and Maldonado [24] also points out that ICT resources are seldom used to meet the educational needs of students. Along the same lines, the study by Altinay and Altinay [31], carried out through documentary analysis and interviews with directors of special education centres, revealed that the use of digital resources is very limited in special education. In this sense, it seems necessary to increase the ICT resources available to favour the inclusion of students with disabilities and promote their correct use by the entire educational community.

Teacher training (FORTIC) includes the assessment of teachers on the training offered and the training received regarding the incorporation of ICTs in the response to students with disabilities. Despite the fact that teacher training is a key factor in promoting the use of ICTs in the field of disability and fostering inclusion [32], several studies have highlighted the lack of training in this area. The study by Toledo and Llorente [33], conducted by questionnaire to 154 students in the Primary Education Degree, concluded that participants had little knowledge about the application of ICTs for people with disabilities, and that this knowledge varied depending on the type of disability. The study by Fernández-Batanero et al. [34], carried out by means of a questionnaire to 341 active teachers, revealed the low level of training of the participants and points to the need to promote didactic training that can be used to train teachers in the use of ICTs to facilitate the learning of students with disabilities, as well as educational innovation. The barriers that hinder the participation of teachers in training 
activities aimed at the use of ICTs applied to people with disabilities are related to economic, time and attitudinal factors of teachers [4]. The study by Brodin and Lindstrand [35], carried out by means of a questionnaire administered to 618 education and special education teachers and interviews with 30 teachers and directors, highlighted the need for teacher training expressed by the participants, as well as the lack of time and economic resources.

Considering the above-mentioned studies, we find aspects that have not been sufficiently addressed, especially when we refer to the analysis of the role of ICT in the process of inclusion of students with Special Educational Needs associated with disabilities. Questions arise about the didactic use and not only as a means of access to knowledge: What is availability of technological resources in the centres? What perceptions do teachers have about their training in technologies in relation to the educational response to students with disabilities? Questions that were not answered adequately after the documentary review was carried out. Consequently, the following objectives emerged: (a) To identify key educational aspects in the use of ICT for inclusion; (b) To ascertain the availability of spaces and ICT resources to serve students with disabilities; (c) To recognise the assessment of teachers on training in ICT to meet the diversity requirements.

It should be noted that this study presented is part of an $\mathrm{R}+\mathrm{D}+\mathrm{I}$ research project entitled "Evaluation of the response to students with specific educational support needs associated with disability in compulsory education: current situation and proposal for improvement" (EDU2016-75574-P).

\section{Materials and Methods}

\subsection{Participants}

The participants in this study were educational professionals related to the field of diversity response, with a total of 2396 responses. Of these, 1626 (68\%) were women and 768 (32\%) were men. According to the type of centre studied, we had 1624 (67.7\%) responses from public centres and $772(32.3 \%)$ from private subsidised centres. The most important data were 1598 (66.7\%) from the urban context and 798 (33.3\%) from the rural context. Finally, it should be noted that these data come from the territorial scope of Spain. It should also be noted that, given that no personal data was requested at any time, the responses were anonymous at all times and no information was requested that would have put people or entities at risk; it was not necessary to request special authorisation according to international regulations.

\subsection{Instrument}

The questionnaire, DISTIC5, used was a section of the general questionnaire used in the R + D + I project to evaluate the educational response to students with SEN-associated with disability in Compulsory Education.

The section explained in this article corresponds to the items referring to the use of ICT in the response to students with disabilities. Initially it had 14 items, which after the process explained below was reduced to 8 items. The technical characteristics of this section of the questionnaire are as follows:

\subsubsection{Validity of Content}

The content was validated by expert judgement. For the selection of experts, the coefficient of expert competence [36] was applied. Fifteen experts were selected, and they attained scores above 0.85 in the expert competence coefficient (CCE) (Table 1). They assessed the content of the questions with respect to the criteria of consistency, technical quality and relevance.

Table 1. Average Expert Competence Coefficient (CCE).

\begin{tabular}{ccccc}
\hline & Teaching & Publications & Investigation & CCE \\
\hline Media of experts & 0.93 & 0.89 & 0.88 & 0.90 \\
\hline
\end{tabular}


As a result of this assessment, two items that were rated low were eliminated, and the wording of three items was changed.

The questionnaire assumeed a Likert scale as the response format with 5 levels, from 1 to 5 .

\subsubsection{Construction Validation}

With the items selected after the content validation, the statistical study was carried out. By applying confirmatory factor analysis and by means of structural equations, the study obtained three factors with which $64.48 \%$ of the variance is explained.

KMO and Bartlett's test of sphericity was applied, and a value of 0.891 and a significance of 0.000 according to the coefficient of Bartlett was obtained.

By processing the data with the AMOS V24, the following equation was obtained (Figure 1).

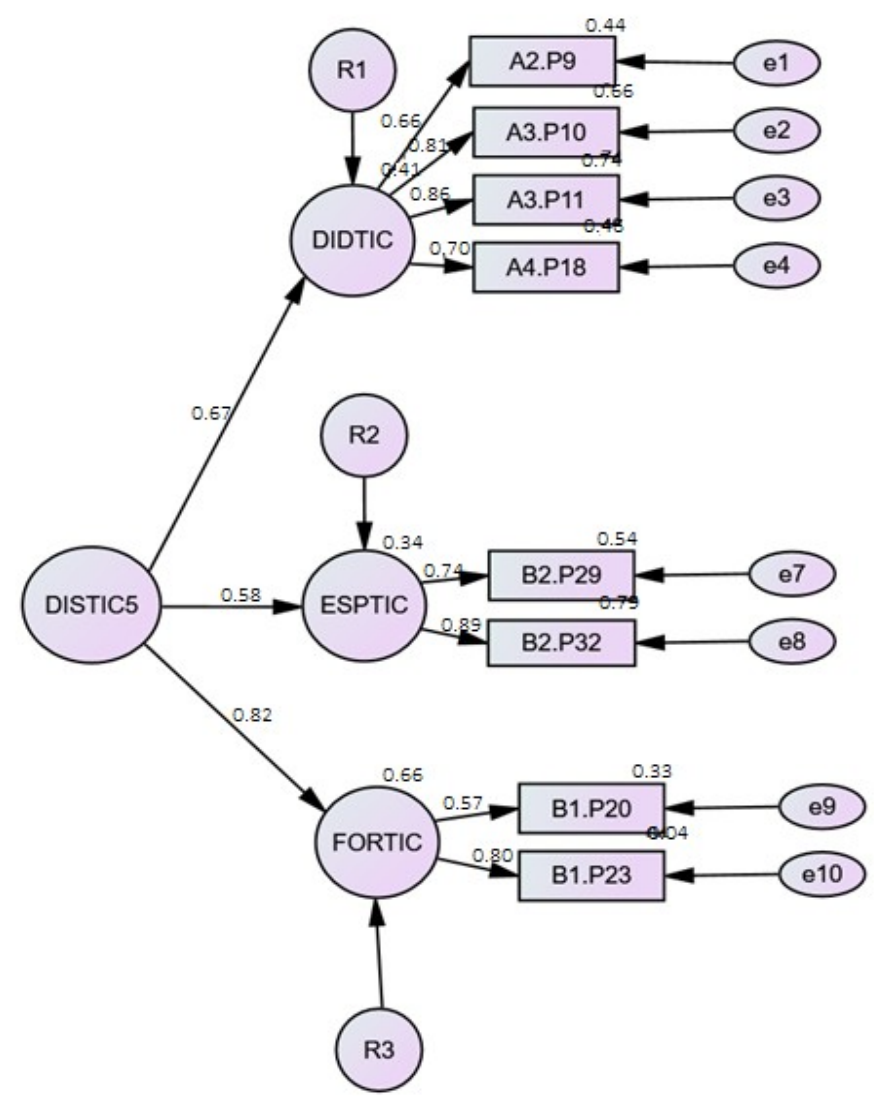

Figure 1. Structural equation DISTIC questionnaire.

In a primary analysis, the non-statistical values did not support the proposed factorial model, so the model was rectified according to the data obtained. Two items with low correlations were eliminated. The following results were obtained for this second model (Table 2):

Table 2. Values of the proposed model.

\begin{tabular}{ccccc}
\hline$p$ Values & RMSEA & CFI & TLI & NFI \\
\hline 0.07 & 0.049 & 0.962 & 0.938 & 0.960 \\
$>0.05$ & $<0.050$ & $>0.90$ & $>0.90$ & $>0.90$ \\
\hline
\end{tabular}

According to Schulenberg and Melton (2010), the values obtained confirm this assessment. Therefore, the questionnaire was structured around three factors (Table 3): 
Table 3. DISTIC5 questionnaire factors.

\begin{tabular}{cc}
\hline Factor & Identification Factor \\
\hline 1 & Didactic aspects (DIDTIC) \\
2 & Spaces and Resources (ESPTIC) \\
3 & Teacher training (FORTIC) \\
\hline
\end{tabular}

\subsubsection{Reliability Study}

The reliability study was carried out using Cronbach's alpha statistic. It was carried out both at the global level of the questionnaire and for each of the factors, obtaining the following results (Table 4).

Table 4. Cronbach alpha values.

\begin{tabular}{ccc}
\hline Factor & & Cronbach's Alpha Values \\
\hline & Questionnaire overview & 0.915 \\
1 & Didactic Aspects (DIDTIC) & 0.841 \\
2 & Spaces and Resources (ESPTIC) & 0.889 \\
3 & Teacher Training (FORTIC) & 0.828 \\
\hline
\end{tabular}

To reinforce the information on reliability, the omega coefficient was applied. This calculation is not incorporated in SPSS (v24), therefore it was carried out by direct calculation with the support of the Microsoft Excel tool. The data obtained provide high reliability (Table 5)

Table 5. Omega coefficient values.

\begin{tabular}{ccc}
\hline Factor & & Valor Coeficiente Omega \\
\hline & Global del cuestionario & 0.943 \\
1 & Aspectos didácticos (DIDTIC) & 0.873 \\
2 & Espacios y recursos (ESPTIC) & 0.871 \\
3 & Formación de docentes (FORTIC) & 0.799 \\
\hline
\end{tabular}

Likewise, the Kolmogorov-Smirnov coefficient was applied to determine the normality of the curve, obtaining a value of $p>0.05$ for all variables. These values enabled us to find the significance of the mean differences based on the independent variables considered.

\subsection{Procedure}

The questionnaire was applied telematically using Google Forms. For this, we previously obtained the database of Pre-school and Primary Education centres throughout the Spanish territory. With this database, we sent emails to those responsible for the care of students with disabilities. In that email, we explained the intention of the study, ensured the confidentiality of the data and informed that the responses should be based on their own perceptions and experiences. In total, 6000 emails were sent, receiving the 2396 responses that made up the study.

\subsection{Data Analysis Plan}

The following process was followed for the analysis and interpretation of the data.

(1) Item-by-item data analysis: means and variance studies

(2) Study of possible differences according to the different social groups that respond to the questionnaire

(3) Interpretation of data grouped by the factors obtained 


\section{Results}

The explanation of the data obtained is grouped by factors for a better clarity.

\subsection{Factor Data 1 (DIDTIC): Didactic Aspects}

This factor was composed of 4 items from which we obtained the following results (Table 6):

Table 6. Factor values of DIDTIC.

\begin{tabular}{ccccc}
\hline \multicolumn{1}{c}{ Items } & Mean & $\begin{array}{c}\text { Standard } \\
\text { Deviation }\end{array}$ & Skewness & Kurtosis \\
\hline $\begin{array}{c}\text { ICTs encourage collaboration between students in } \\
\text { the classroom }\end{array}$ & 3.78 & 1.000 & -0.695 & 0.025 \\
$\begin{array}{c}\text { The Programming Units are designed to incorporate } \\
\text { the use of ICT }\end{array}$ & 3.93 & 0.944 & -0.635 & -0.239 \\
$\begin{array}{c}\text { ICTs are used as a tool to adapt learning processes to } \\
\text { students with disabilities }\end{array}$ & 3.66 & 0.940 & -0.469 & -0.139 \\
$\begin{array}{c}\text { Evaluation methods and techniques with students } \\
\text { with disabilities incorporate the use of ICT }\end{array}$ & 3.68 & 0.918 & -0.491 & -0.090 \\
\hline
\end{tabular}

It is noteworthy in these data that, in general, the average is very close to the central axis (score 3). Likewise, the low value of kurtosis indicates that the tails of the curve are light.

In the second section we attempted to discover if there were significant differences according to the three independent variables: sex, ownership of the centre (public or private), and location of the centre (urban, rural).

We observed that after the application of the Student's t statistic with respect to the variable 'sex' that no significant differences were observed.

However, regarding the locations of the centres, in all cases the differences were significant, although the effect size (Cohen's d) was low (Table 7):

Table 7. Differences depending on the location of the centre.

\begin{tabular}{cccc}
\hline Items & T & Sig & Effect Size \\
\hline $\begin{array}{c}\text { ICTs encourage collaboration between students in } \\
\text { the classroom }\end{array}$ & 2.725 & 0.006 & 0.114 \\
$\begin{array}{c}\text { The Programming Units are designed to incorporate } \\
\text { the use of ICT }\end{array}$ & 4.541 & 0.000 & 0.181 \\
$\begin{array}{c}\text { ICTs are used as a tool to adapt learning processes to } \\
\text { students with disabilities }\end{array}$ & 3.692 & 0.000 & 0.147 \\
$\begin{array}{c}\text { Evaluation methods and techniques with students } \\
\text { with disabilities incorporate the use of ICT }\end{array}$ & 2.589 & 0.010 & 0.101 \\
\hline
\end{tabular}

When we made comparisons on the basis of the ownership of the centre, we found that for the first item there was no significant difference, but in the following cases (Table 8):

Table 8. Differences according to ownership.

\begin{tabular}{cccc}
\hline Items & T & Sig & Effect Size \\
\hline $\begin{array}{c}\text { The Programming Units are designed to incorporate } \\
\text { the use of ICT }\end{array}$ & 3.296 & 0.001 & 0.134 \\
$\begin{array}{c}\text { ICTs are used as a tool to adapt learning processes to } \\
\text { students with disabilities }\end{array}$ & 2.824 & 0.005 & 0.116 \\
$\begin{array}{c}\text { Evaluation methods and techniques with students } \\
\text { with disabilities incorporate the use of ICT }\end{array}$ & 2.314 & 0.02 & 0.093 \\
\hline
\end{tabular}




\subsection{Data Factor 2 (ESPTIC): Spaces and Resources}

With regard to the second factor related to the spaces in which students live together, we found the following results (Table 9):

Table 9. Factor values ESPTIC.

\begin{tabular}{cccc}
\hline Items & Mean & $\begin{array}{c}\text { Standard } \\
\text { Deviation }\end{array}$ & Skewness \\
\hline $\begin{array}{c}\text { Ordinary classrooms are equipped with technological } \\
\text { resources to assist students with disabilities }\end{array}$ & 3.34 & 1.044 & -0.263 \\
$\begin{array}{c}\text { The school's spatial organisation allows it to meet the } \\
\text { needs of students with disabilities }\end{array}$ & 3.33 & 1.043 & -0.561 \\
\hline
\end{tabular}

As in the case of the first factor, the data are very close to the central value (3). Likewise, the data on asymmetry indicate that the trend is below the average. Finally, the data referring to kurtosis indicates that the curve is not very accentuated, with the tails not very far from the average.

It was intended in the data analysis plan, therefore we want to identify the possible differences due to the independent variables of socio-demographic character.

In the first case, the gender variable, as in the previous cases, after the application of the Student's $t$-test, no significant differences were observed.

For the variable referring to the location of the centre (urban, rural) equally we did not find significant differences.

With regard to the differences in this factor referring to the ownership of the centre, we found differences in the case of the item related to the organisation of the spaces, although the effect size (Cohen's d) was low (Table 10).

Table 10. Significant differences between public and private centres.

\begin{tabular}{cccc}
\hline Items & T & Sig & Effect Size \\
\hline $\begin{array}{c}\text { The school's spatial organization allows it to meet } \\
\text { the needs of students with disabilities }\end{array}$ & 4.038 & 0.000 & 0.184 \\
\hline
\end{tabular}

\subsection{Data Factor 3 (FORTIC): Teacher Training}

The following is the data on teacher training for educational response. In this case, we see that in the item referring to training provision the average is below the central value (3) (Table 11)

Table 11. Factor values FORTIC.

\begin{tabular}{|c|c|c|c|c|}
\hline Items & Mean & $\begin{array}{l}\text { Standard } \\
\text { Deviation }\end{array}$ & Skewness & Kurtosis \\
\hline $\begin{array}{l}\text { How do you assess your training with regard to the } \\
\text { incorporation of ICTs in the response to students } \\
\text { with disabilities? }\end{array}$ & 3.40 & 1.039 & -0.386 & -0.446 \\
\hline $\begin{array}{l}\text { The training offer received by teachers in relation to } \\
\text { the use of ICTs in the care of students with disabilities }\end{array}$ & 2.72 & 1.118 & -0.102 & -0.863 \\
\hline
\end{tabular}

Although the first item shows an average of 3.40, the asymmetry gives us a negative value, indicating that the data are below the average. For the second item, the value of kurtosis is noteworthy as it indicates a very pointed curve, demonstrating that the data are positioned very close to the average.

Below, we show the data referring to possible significant differences according to the independent variables considered.

In the first case, sex, we still did not find significant differences. When we studied the differences due to the location of the centre, we only found differences in the first item, with low effect size (Cohen's d) (Table 12) 
Table 12. Differences depending on the location of the centre.

\begin{tabular}{cccc}
\hline Items & T & Sig & Effect Size \\
\hline $\begin{array}{c}\text { How do you assess your training with regard to the } \\
\text { incorporation of ICTs in the response to students } \\
\quad \text { with disabilities? }\end{array}$ & 2.113 & 0.03 & 0.095 \\
\hline
\end{tabular}

The significance is minimal, as is the size of the effect.

With regard to the variable of ownership of the centre, significant differences can be seen in both items, highlighting how the public centres have a better educational offer and the teachers feel better prepared than in the private centres (Table 13).

Table 13. Differences depending on the ownership of the centre.

\begin{tabular}{lccc}
\hline \multicolumn{1}{c}{ Items } & T & Sig & Effect Size \\
\hline $\begin{array}{l}\text { How do you assess your training with regard to the } \\
\text { incorporation of ICTs in the response to students } \\
\quad \text { with disabilities? }\end{array}$ & 2.566 & 0.01 & 0.119 \\
$\begin{array}{l}\text { The training offer received by teachers in relation to } \\
\text { the use of ICTs in the care of students with disabilities }\end{array}$ & 2.394 & 0.01 & 0.152 \\
\hline
\end{tabular}

In both cases the size of the effect is low (Cohen's d).

\section{Discussion}

As highlighted in the introduction, ICTs take on special relevance in the educational response to students with disabilities. The postulates of the Universal Learning Design (ULD) [15,16,37-39] frame the incorporation of ICT in the educational response to students with disabilities from a didactic point of view, in such a way that these bases of the ULD are supported, among other pillars, by the technological advances that come from ICTs. Hence, there is a special importance of an adequate and timely didactic incorporation of ICT in the educational response to students with Special Educational Needs associated with disability.

From the data obtained, it can be seen that a large majority of participants have placed their responses around the central trend. In no case was an average equal or greater than value 4 (scale from 1 to 5) obtained, although the asymmetry values indicated shifts in the curve to the left. This suggests that the relationship between the use of ICT with regard to students with disabilities is not acceptable in terms of the requirements needed to respond to students with disabilities in inclusive contexts.

It is particularly striking in the first factor how there are significant differences between centres located in urban and rural contexts. The same applies to the ownership of the centre. This indicates that public centres in urban contexts are the ones which are best prepared, in terms of didactic aspects, to operate inclusive environments. This is very significant, as it creates a gap between groups or populations situated in urban or rural contexts, the latter being at a clear disadvantage in terms of students' disability provision. These data coincide with studies carried out on education in rural contexts [40-42] which have shown how, in general, geographical location presents characteristics which place them at a differential disadvantages. Not only in general areas, but also, as is the object of this study, in terms of the level of resources available to respond to this particular group of students.

Regarding the second dimension, we found few significant differences. The only difference that stood out was the availability of specific spaces for care, with the private centres being those that showed less availability.

Contrast these data with dimension 1, i.e., no differences between urban and rural centres. This fact may indicate that the availability of space is consistent, because the building and general planning of these centres is more or less uniform. However, they may not be fully equipped as previously appreciated. This idea is reinforced by the appreciation of significant differences between 
public and private subsidised centres. In the former, these buildings and different services are designed by a single administration. The subsidised private centres, because they depend on a titular entity, are not unified in their distribution and level of service. Hence, the differences between these two populations.

Finally, with regard to the training dimension, on the one hand, we found that urban centres have better programmes offered than rural ones. These data allow us to relate the effects found in the first dimension, didactic aspects, with the significant difference between the two spaces and the teacher training received, which is also better appreciated in urban environments than in rural ones. This same situation explains the difference between public and private subsidised centres. The lower level of training offered in the latter has an impact on the didactic aspects developed in these centres. These data can be related to studies on teacher training to respond to intercultural situations [43].

The centres located in rural contexts are designed and equipped from a single administration, and therefore in the same way as the centres located in urban contexts, although they do not have all the training on offer for teachers as is the case for teachers working in urban centres. This can be seen in these differences in the didactic use of technologies. As previously mentioned, this opens up a new gap in knowledge- the digital divide, in our case - and therefore in the quality of response to the group of students with disabilities.

Similarly, we can say that the variable ownership of the centre results in different levels of education provision. The private centres are mostly located in urban contexts. Therefore, the differences with regard to the training offered can be found in the availability of training courses for the teachers of these centres, which in general do not participate in the offers that the public administrations propose for the teachers of public centres.

For the statements regarding the significant differences found with Student's $t$-tests and ANOVA, we have considered the values obtained with these statistically, although it is convenient to refer to the effect sizes indicated by Cohen's d coefficient. In all cases they were small $(\mathrm{d}<0.4)$. Which should be interpreted as that, although there are significant differences, they are not excessively important [44].

\section{Conclusions}

Based on the results and taking into account that for an adequate implementation of the Universal Learning Design (ULD), ICTs are a fundamental pillar of the methodological actions that are proposed, we can observe how the panorama moves away from what would be the ideal scenario so that its implementation is carried out in the best conditions.

It is also worth noting that public schools, located in urban contexts, seem to be better prepared for the development and support of ICTs in educational activities in which students with disabilities are immersed.

Better training offered to both teachers in schools located in rural areas, as well as those who work in private schools, would undoubtedly contribute to improving the educational offer in inclusive contexts.

In short, we can see the existing gap between urban and rural centres, which is manifested around this variable of the incorporation of technologies in learning processes. This situation leads to the idea that inclusion processes have more difficulties in their development in rural centres than in urban ones.

Finally, this study presents some key implications to achieve an adequate level of ICT incorporation in the educational response to students with disabilities. Strengthening the teachers' training oriented to relationships between ICT and disability is vital, with a special emphasis on teachers who work in rural centres. This improvement in teacher training could lead to a better use of existing resources. Insistence on the idea of guiding the training not only in the knowledge of the resources, but also in the didactic use, a deficiency detected both in the studies reviewed and in the data obtained, would also be beneficial.

On the other hand, also supported by the reviewed studies and research data, we consider that emphasis should be placed on reducing the disparity between rural and urban centres. It is a variable, the location of the centre, which can generate a new form of discrimination and with special incidence 
in students with disabilities due to the lack of teachers with sufficient training in the didactic use of technologies in these groups.

Author Contributions: Conceptualization, L.O.-J. and V.F.-C.; methodology, L.O.-J.; validation, L.O.-J.; M.C.L. and V.F.-C.; formal analysis, L.O.-J.; investigation, L.O.-J.; V.F.-C.; M.C.L. and M.C.L.B.; writing-original draft preparation, L.O.-J., M.C.L. and M.C.L.B.; writing-review and editing, V.F.-C.; supervision, L.O.-J.; project administration, L.O.-J. All authors have read and agreed to the published version of the manuscript.

Funding: This research was funded by the $\mathrm{R}+\mathrm{D}+\mathrm{I}$ project of the national call of the Spanish government EDU2016-75574-P. "Study on educational response to students with Specific Educational Support Needs Associated with Disability".

Conflicts of Interest: The authors declare no conflict of interest.

\section{References}

1. Pacheco-Méndez, T. Las Ciencias Sociales mediadas por las TIC. Rev. Iberoam. Cienc. Tecnol. Soc.-CTS 2017, 12, 179-195.

2. Falloon, G. What's the difference? Learning collaboratively using iPads in conventional classrooms. Comput. Educ. 2015, 84, 62-77. [CrossRef]

3. Ortiz-Jiménez, L.; López-Meneses, E.; Figueredo-Canosa, V.; Martín-Padilla, A.H. Diversidad e Inclusion Educativa: Respuestas Innovadoras con Apoyo en las TIC, 1st ed.; Octaedro: Barcelona, Spain, 2018.

4. Fernández-Batanero, J.M.; Reyes, M.M.; El Homrani, M. TIC y discapacidad. Principales barreras para la formación del profesorado. EDMETIC 2018, 7, 1-25. [CrossRef]

5. Cabero, J.; Fernández-Batanero, J.M.; Barroso, J. Los alumnos del grado de magisterio: TIC y discapacidad. Rev. Electron. Investig. Educ. 2016, 18, 106-120.

6. Dobransky, K.; Hargittai, E. The disability divide in internet access and use. Inf. Commun. Soc. 2006, 9, 313-334. [CrossRef]

7. Cabero, J.; Córdoba, M.; Fernández, J.M. Las TIC para la Igualdad. Nuevas Tecnologías y Atención a la Diversidad; Eduforma: Sevilla, Spain, 2007.

8. D'Aubin, A. Working for barrier removal in the ICT area: Creating a more accessible and inclusive Canada. Inf. Soc. 2007, 23, 193-201. [CrossRef]

9. Stendal, K. How do people with disability use and experience virtual worlds and ICT: A literature review. J. Virtual Worlds Res. 2012, 5, 1-17. [CrossRef]

10. Kent, M. Disability and eLearning: Opportunities and barriers. Disabil. Stud. Q. 2015, 35. [CrossRef]

11. Chadwick, D.; Wesson, C. Digital Inclusion and Disability. In Applied Cyberpsychology; Attrill, A., Fullwood, C., Eds.; Palgrave Macmillan: London, UK, 2016; pp. 1-23.

12. Turner-Cmuchal, M.; Aitken, S. ICT as a Tool for Supporting Inclusive Learning Opportunities. In Implementing Inclusive Education: Issues in Bridging the Policy-Practice Gap; Watkins, A., Meijer, C., Eds.; Emerald Group Publishing: Bingley, UK, 2016; Volume 8, pp. 159-180. [CrossRef]

13. Drigas, A.S.; Ioannidou, R.E. ICTs in Special Education: A Review. In Information Systems, E-Learning, and Knowledge Management Research; Communications in Computer and Information Science; Springer: Berlin/Heidelberg, Germany, 2013; Volume 278, pp. 357-364.

14. Ministerio de Sanidad, Servicios Sociales e Igualdad. Plan de Acción de la Estrategia Española de Discapacidad 2014-2020, Aprobado por Acuerdo del Consejo de Ministros el Día 12 de Septiembre de 2014. Available online: https://www.mscbs.gob.es/ssi/discapacidad/docs/plan_accion_EED.pdf (accessed on 3 September 2020).

15. Katz, J. The three Block Model of UDL: Engaging students in inclusive education. Can. J. Educ. Adm. Policy 2013, 36, 153-194.

16. Novak, K. UDL Now! A Teacher's Monday Morning Guide to Implementing Common Core Standars Using Universisal Desing for Learning; CAST Professional Publishing: Wakefield, MA, USA, 2014.

17. Cothren, S.; Rao, K. Systematically Applying UDL to Effective Practices for Students with Learning Disabilities. Learn. Disabil. Q. 2018, 41, 179-191. [CrossRef]

18. Córdoba, M.; Cabero, J.; Soto, F.J. Buenas Prácticas de Aplicación de las TIC para la Igualdad; Eduforma: Sevilla, Spain, 2012. 
19. Toledo, P. Las Tecnologías de la Información, la Comunicación y la Inclusión Educativa. In Nuevos Escenarios Digitales; Barroso, J., Cabero, J., Eds.; Pirámide: Madrid, Spain, 2013; pp. 411-426.

20. Macdonald, S.J.; Clayton, J. Back to the future, disability and the digital divide. Disabil. Soc. 2013, 28, 702-718. [CrossRef]

21. Abascal, J.; Barbosa, S.D.; Nicolle, C.; Zaphiris, P. Rethinking universal accessibility: A broader approach considering the digital gap. Univers. Access Inf. Soc. 2015, 15, 179-182. [CrossRef]

22. Cabero, J. La educación a distancia como estrategia de inclusión social y educativa. Rev. Mex. Bachill. Distancia 2016, 8, 138-147. [CrossRef]

23. Adam, T.; Tatnall., A. Using ICT to Improve the Education of Students with Learning Disabilities. In Learning to Live in the Knowledge Society; Springer: Boston, MA, USA, 2008; Volume 281, pp. 63-70. [CrossRef]

24. King-Sears, M. Universal Design for Learning: Technology and Pedagogy. Learn. Disabil. Q. 2009, 32, $199-201$. [CrossRef]

25. Cabero, J. TICs para la igualdad: La brecha digital en la discapacidad. An. Univ. Metrop. 2008, 8, 15-43.

26. Observatorio Estatal de la Discapacidad. Alumnado con Discapacidad y Educación Inclusiva en España; Observatorio Estatal de la Discapacidad: Badajoz, Spain, 2019.

27. Arnaiz, P.; De Haro, R.; Maldonado, R. Barriers to student learning and participation in an inclusive school as perceived by future education professionals. J. N. Approaches Educ. Res. 2019, 8, 18-24. [CrossRef]

28. Alba, C.; Zubillaga, A. De la accesibilidad de las tecnologías a la educación accesible: Aportaciones del Diseño Universal para el aprendizaje. In Actas de las VIII Jornadas Científicas Internacionales de Investigación sobre Discapacidad; Verdugo, M.A., Nieto, T., Crespo, M., Jordán, F., Eds.; INICO: Salamanca, Spain, 2012.

29. Estes, M.D.; Beverly, C.L.; Castillo, M. Designing for Accessibility: The Intersection of Instructional Design and Disability. In Handbook of Research in Educational Communications and Technology; Bishop, M.J., Boling, E., Elen, J., Svihla, V., Eds.; Springer: Cham, Switzerland, 2020; pp. 205-227.

30. González-Gil, F.; Martín-Pastor, E.; Poy, R. Educación inclusiva: Barreras y facilitadores para su desarrollo. Análisis de la percepción del profesorado. Profr. Rev. Currículum Form. Profr. 2019, 23, 243-263. [CrossRef]

31. Altinay, A.; Altinay, Z. Examination on ICT integration into Special Education Schools for Developing Countries. Turk. Online J. Educ. Technol. 2015, 14, 70-72.

32. Simón, N.; De Cisneros, J.C.; Gértrudix, F. Valoración y uso de las TIC para una transformación e inclusión educomunicativa. Index. Comun. Rev. Cient. Ambito Comun. Apl. 2018, 8, 255-273.

33. Toledo, P.; Llorente, M.C. Formación inicial del profesorado en el uso de tecnologías de la información y la comunicación (TIC) para la educación del discapacitado. Digit. Educ. Rev. 2016, 30, 123-134.

34. Fernández-Batanero, J.M.; Sañudo, B.; Montenegro-Rueda, M.; García-Martínez, I. Physical Education Teachers and Their ICT Training Applied to Students with Disabilities: The Case of Spain. Sustainability 2019, 11, 2559. [CrossRef]

35. Brodin, J.; Lindstrand, P. What about ICT in special education? Special educators evaluate information and communication technology as a learning tool. Eur. J. Spec. Needs Educ. 2003, 18, 71-87. [CrossRef]

36. Almenara, J.C.; Osuna, J.B. La utilización del juicio de experto para la evaluación de TIC: El Coeficiente de Competencia Experta. Bordón. Rev. Pedagog. 2013, 65, 25-38. [CrossRef]

37. Lapinnski, S.; Gravel, W.L.; Rose, D.H. Tools for Practice: The Universal Design for Learning Guidelines; The Guilford Press: New York, NY, USA, 2012.

38. CAST. Universal Desing for Learnning Guidelines. Available online: http://udlguidelines.cast.org/ (accessed on 13 September 2020).

39. Basham, J.; Gardner, J.; Smith, J. Measuring the Implementation of UDL in Classrooms and Schools: Initial Field Test Results. Remedial Spec. Educ. 2020, 41, 231-243. [CrossRef]

40. De la Cruz, E.; Aguirre-Gómez, M.D.; Pino-Ortega, J.; Díaz-Suárez, A.; Valero-Valenzuela, A.; García-Pallarés, J. Diferencias en la condición física en niños de entornos rurales y urbanos. Rev. Psicol. Deporte 2012, 21, 359-363.

41. OECD (The Organisation for Economic Co-Operation and Development). PISA in Focus 28: What Makes Urban Schools Different? Available online: https://www.oecd-ilibrary.org/education/what-makes-urbanschools-different_5k4618w342jc-en\# (accessed on 7 September 2020).

42. Imaniah, I.; Fitria, N. Inclusive education for students with disability. SHS Web Conf. 2018, 42, 1-5. [CrossRef] 
43. Figueredo, V.; Ortiz, L.; Sánchez, C.; López, M.C. Teacher training in intercultural education: Teacher perceptions. Educ. Sci. 2020, 10, 81. [CrossRef]

44. Kelley, K.; Preacher, K.J. On Effect Size. Psychol. Methods 2012, 17, 137-152. [CrossRef]

Publisher's Note: MDPI stays neutral with regard to jurisdictional claims in published maps and institutional affiliations.

(C) 2020 by the authors. Licensee MDPI, Basel, Switzerland. This article is an open access article distributed under the terms and conditions of the Creative Commons Attribution (CC BY) license (http://creativecommons.org/licenses/by/4.0/). 